\title{
Theoretical Models in Psychoanalytic Psychosomatic: A Review
}

\author{
Maíra Bittar Galdi ${ }^{1}$ \\ Faculdade de Ciências da Universidade Estadual Paulista Júlio de Mesquita Filho, \\ Bauru, SP, Brazil \\ Érico Bruno Viana Campos \\ Departamento de Psicologia da Universidade Estadual Paulista Júlio de Mesquita Filho, \\ Bauru, SP, Brazil
}

\begin{abstract}
This article is a theoretical study of the psychoanalytic literature on the subject of psychosomatic that aims to review the approach models this phenomenon seeking to understand their differences and similarities in terms of theoretical basis. The results point to two different ways of looking at psychosomatic illnesses. In the French side, linked more or less directly to the Lacan perspective, the main references were Jacques-Alain Miller and Pierre Marty, the phenomenon is not a representational shift, but a failure in symbolization processes. In a second aspect, which brings together from the Psychosomatic School of Chicago to French authors not Lacanian, the main references were Joyce McDougall and Christophe Dejours, the psychosomatic phenomenon is understood in a divergent line, relating the formation of the symptom the unconscious conflicts. They are symbolized in the disease, but in a more precarious form of symbolization from the model of hysteria. Despite the differences, it is understood that no compromise on the principles towards the treatment, which is to define a meaning for the symptom, not by the rescue of an unconscious fantasy as in the classic model of hysteria, but building a sense where there was no historical narrative thread.
\end{abstract}

Keywords: Psychoanalysis, psychosomatic, somatization, symbolization.

\section{Modelos Teóricos em Psicossomática Psicanalítica: Uma Revisão}

\section{Resumo}

Este artigo é um estudo teórico da literatura psicanalítica sobre o tema da psicossomática que tem por objetivo revisar os modelos de abordagem desse fenômeno buscando a compreensão de suas diferenças e similitudes em termos de fundamentação teórica. Os resultados apontam para duas maneiras distintas de ver as doenças psicossomáticas, ligadas a duas tradições em psicanálise. Na vertente francesa, ligada mais ou menos diretamente à perspectiva lacaniana, cujas principais referências foram Jacques AlainMiller e Pierre Marty, o fenômeno não constitui um deslocamento representacional, mas sim uma falha nos processos de simbolização. Em uma segunda vertente, que congrega a Escola Psicossomática de Chicago até autores franceses não lacanianos, cujas principais referências foram Joyce McDougall e

Mailing address: Rua Christiano Pagani, 8-51, Apto 53ª , Bairro Jardim Auri Verde, Bauru, SP, Brazil 17047144. Phone: (14) 3204-8979/(14) 98111-6015. E-mail: mah.bg@hotmail.com

This work is the result of a scientific initiation research "Essentials of Psychosomatic Psychoanalytic" developed by the first author and guided by the second author in the Getting Started program without Universidade Estadual Paulista "Júlio de Mesquita Filho" - UNESP Exchange (Programa de Iniciação sem Bolsa - PIBICISB). 
Christophe Dejours, o fenômeno psicossomático é compreendido em uma linha divergente, relacionando a formação do sintoma a conflitos inconscientes que são simbolizados na doença, mas em uma forma de simbolização mais precária em relação ao modelo da histeria. Apesar das divergências, entende-se que há conciliação quanto aos princípios na direção do tratamento, que consiste em definir um sentido para o sintoma, não por meio do resgate de uma fantasia inconsciente como no modelo clássico da histeria, e sim construindo um sentido onde não havia encadeamento histórico-narrativo.

Palavras-chave: Psicanálise, psicossomática, somatização, simbolização.

\section{Modelos Teóricos en Psicosomática Psicoanalítica: Una Revisión}

\section{Resumen}

Este artículo es un estudio teórico de la literatura psicoanalítica sobre el tema de psicosomática que tiene como objetivo revisar los modelos de aproximación a este fenómeno que tratan de comprender sus diferencias y similitudes. Los resultados apuntan a dos formas diferentes: En el lado francés, vinculado más o menos directamente a la perspectiva Lacaniana, las referencias principales fueron Jacques-Alain Miller y Pierre Marty, el fenómeno no es un cambio de representación, pero un fallo en los procesos de simbolización. En un segundo aspecto, que reúne en la Escuela Psicosomática de Chicago a los autores franceses no Lacanianos, las referencias principales fueron Joyce McDougall y Christophe Dejours, el fenómeno psicosomático se entiende en una línea divergente, relativa a la formación del síntoma los conflictos inconscientes Ellos están simbolizadas en la enfermedad, pero en una forma más precaria del modelo de la histeria. A pesar de las diferencias, se entiende que hay compromiso en los principios hacia el tratamiento, que consiste en definir un significado para el síntoma, no por el rescate de una fantasía inconsciente como en el modelo clásico de la histeria, pero la construcción de un sentido en que no había ningún hilo narrativo histórico.

Palabras clave: Psicoanálisis, psicosomática, somatización, simbolización.

In the nineteenth century, the emergence of cases of hysteria brought difficult questions to the fields of scientific and naturalistic medicine. In a historical context, where reason and the cult of conscience prevailed, symptoms such as paralysis and inhibitions that had no organic correspondence intrigued and posed a challenge for the epoch. This allowed other sciences, which were not enclosed in positivist logic, to cast them into the guidelines of a theoretical framework that could cope with this reality. Accordingly, in the context of Freud and Breuer's (1895) studies on hysteria, the concept of the "unconscious" will be outlined as well as the techniques and methods that allow for its research, leading to the composition of a new science - Psychoanalysis - constituted by an object and a specific method.

Initially investigated through hypnosis techniques, the "unconscious" was discovered as having its own operating laws fleeing fully to consciousness, and it was through these laws that Freud uncovered the conversive mechanism that was behind the hysteria symptoms.

The conversion was described by Freud as an unconscious mechanism, present in the clinical matrix of hysteric neurosis, wherein the drive connected to an idea is repressed and converted into ideational representatives on the body. However, it is not the biological body but the erogenous body that is endowed with an imaginary anatomy, which subverts the real body so that the erogenous order is comprised as a double of the biological order created from the body surface area (Leclaire, 1979/1992). The erogenous body is one that has, in its imaginary anatomy, specific sexual fantasies that somehow are connected to a corresponding organ. It is therefore a desiring body, which exceeds the biological determinism: the organs are not only used to meet the survival needs, as in the animal, 
but also meet, express, and evoke desires and that is what makes a man stand out from the animals: he has drive impulses and not instincts.

However, the erogenous body is not born with the human being. In order for it to exist and develop, someone else must invest in it sexually. In other words, to wish for it, is as to imagine a story and direct his eyes to the body. This whole process is not simple - it runs from the stage of primary narcissism till the later stages of sexuality construction - and always, by some misfortune of life to which all are subject, it can be stopped if it is disrupted or regresses to earlier stages of development. The erogenous body is also likely to fail. The libidinal investment is never uniform: one can invest too much in a region, as in hysteria, or fail to invest in another, as is supposed to happen in the psychosomatic phenomenon. This issue is a result of some theoretical differences in the field.

Thus, psychoanalysis, in its discovery and research of the conversion mechanism, shook the pillars of the Cartesian rationalism, definitely breaking apart from medicine. It introduced the concept of the erogenous body, ushering in a new form of knowledge: the unconscious. It is for this reason that speaking in psychosomatic psychoanalysis proves to be a thorny issue. How is it possible to theorize about what psychoanalysis itself denied in its origin as a field of knowledge? While this denial of the real body set on its break with positivism, it now divides and stands as a contemporary challenge, currently, as the psychic malaise has its various expressions in the biological body.

However, the question "what is psychosomatics?" arises. This issue is also presented in a diffused manner. Even in medicine we can see differences in its definition. A trend of Hippocratic-influenced medicine considers psychosomatics as a philosophy - a vision of man and world where the body and mind are not divided. It all covers the psyche and soma, that is, both health and disease are part of unified mental and somatic processes that constitute humans as a whole. Another trend considers that only certain types of diseases are psychosomatic, which withdraws dualistic discussions, as from this perspective, there are diseases that involve the psyche and others that do not (Mello \& Burd, 2010). With regard to the latter aspect, we see that even with the split in medicine in which psychoanalysis appeared in some respects they still approach, such as the description and categorization of these diseases, correlating them with specific unconscious conflicts undertaken by the Chicago School (Casetto, 2006).

Thus, the fine line between physiological and psychological processes is again questioned with the reintegration of psychoanalysis in the issues regarding the real aspects of the body. From this line of research appears the notion that, in addition to the fantasies that are symbolized on an imaginary anatomy, the biological body may also serve as outlet for unnamed fantasies and even support poor symbolizations or more archaic modes of representation as those considered in the classical neurotic model. However, the different strands of psychoanalytic schools are divided as to the specific nature of this phenomenon, bringing convergences and divergences between them.

The main points of discussion lie in the elucidation of (a) if there is a specific clinical entity present in psychosomatic cases; (b) how the symbolic processes are articulated in them; (c) the still-current challenge to write a metapsychological description of this kind of phenomena. For this, we studied some of the leading theorists in this subject: Franz Alexander, leader of Psychosomatic School of Chicago; Pierre Marty, from the Psychosomatic Institute of Paris (IPSO); and Jacques-Alain Miller, Joyce McDougall and Christophe Dejours.

\section{Description}

Psychoanalysis, in general, considered psychosomatic illness to be every phenomenon that is not restricted to medical biological explanations that insists on appearing as a symptom but one that does not fit the classic features of neurotic conversion. It is a diagnosis, therefore, by exclusion, which is why so many rumors emerged - mainly from authors near Lacan because otherwise, we would be facing a new 
clinical matrix other than the classical neuroses, psychoses, and perversions.

From this group of researchers, Pierre Marty is the most representative of this line of thought. Known as the leader of the IPSO, his work is basically divided into three periods. In the first, the more biological, psychosomatic disorganization process is considered as a result of tension between life and death instincts. These would have a somatic source and death was not the end; however, the consequence of this biological imbalance is contrary to what was claimed by Lacan's theory and other members of the institute. Thus, the disruptions first hit the areas of the erogenous body to protect the body from major disruptions until the psyche is re-established. If the disruption is more serious, it can compromise the biological body and can even cause death. According to Marty, the psyche is evolutionarily more recent than the somatic points (Casetto, 2006), and, therefore, it is the first to be hit in the result of a trauma.

The second part of Marty's work focused on a more psychoanalytical theoretical construct with the introduction of his key concepts: mentalization, operational thinking, and essential depression. For him, a low mentalizing ability, that is, the capacity of metabolizing trauma through symbols, takes the subject to what is called essential depression. This is characterized by a depression without specific object, very different from mourning, for example, that generally has the object lost a component with the consequent uninvestiment of its libido. The psychic devitalization of essential depression has its corresponding investment in suicidal or detractor thoughts, as occurs in cases of classic depression. There is a massive disinvestment; it is not so much of sadness, but of apathy, thus increasing the frequency of illness and psychosomatic accidents.

In the last phase of his work, Marty formulated a nosological classification of psychosomatic, according to different categories in relation to mentalizing ability. They would be lower as compared to the symbolization capacity on the neurotic, psychotic, and perverse subjects: "Initially called them behavior and character neurosis, and then subdivided the latest in badly mentalized neurosis, uncertainly mentalized neurosis, and well mentalized neurosis" (Casetto, 2006, p. 12).

Perhaps an influence of his biologicist phase, Vieira (1997) points out to Marty, that the psychosomatic illness does not have the role that the death drive has to Freud because their ultimate goal is not death; however, it can be a defense, preventing more severe disruptions, working to ensure the body's integrity. Gradually, the concepts of mentalization and operational thinking stood out if compared to other theoretical aspects of his journey, such as the concept of essential depression, even on the more focused phase of biological description. His theoretical contribution is quite marked by highlighting the lack of symbolization of the psyche in psychosomatic patients, and this aspect will be thoroughly examined and questioned in this study.

Another major aspect in psychosomatic psychoanalytic was the School of Chicago, led by Franz Alexander. It limits psychosomatic diseases in seven classical disorders: bronchial asthma, gastric ulcer, rheumatoid arthritis, ulcerative colitis, dermatitis, tireotoxicoses, and hypertension. Unlike what happens with hysteria, Volich (2000) points out that Alexander does not consider the phenomenon as a compromise, that is, the phenomenon is not an attempt to cure and solve psychic conflict. Alexander developed the notion of specific psychodynamic constellation to explain the origin of the disease. It proposes that certain internal conflicts are directly related to specific emotional reactions, each corresponding to each conflict, although the relationship between emotions and disease is not causal.

These two great schools played a very important role, both in practice and the construction of a psychoanalytic theory about psychosomatic diseases. They were responsible for building a theoretical body - these buildings blocks were later supported, modified, and problematized by psychoanalysts - contributing to the advancement of knowledge in this relatively new subject. In subsequent discussions, we find important theoretical frameworks in Jacques-Alain Miller, Joyce McDougall, and Christophe Dejours. 
Until then, the theoretical constructs on the psychoanalytic psychosomatic did not consider the possibility of the development of psychosomatic diseases in other subjective structures than those that function in the operational thinking mode. On this point, Miller (1987) considered the existence of the phenomena in other subjective structures; however, he did not cease to theorize about a possible psychosomatic subjective structure of its own.

According to Miller, the psychosomatic can be a very primitive structure, close to psychosis and mental retardation. The opposite relation between a psychosomatic phenomenon and the hysterical symptom becomes quite evident. The difference lies in the fact that, unlike what occurs in the phenomenon, the conversion symptom does not focus on the real (biological) body but on the erogenous (imaginary) body. According to Miller, the symptom lies in the field of neuroses and obeys an underlying language structure, which operates through metaphor and displacement processes and, therefore, full of unconscious meanings that do not occur in the psychosomatic phenomena.

Certainly, it is crucial, and essential, distinguishing symptom, especially hysterical, from psychosomatic phenomenon, precisely in this relation to the Other that is constitutive of the hysterical symptom, which is in no way the case of psychosomatic phenomenon, if it exists. (Miller, 1987, p. 89)

The phenomenon is not inserted in a language structure; however, it is not completely out of it. This is what characterizes it as a threshold phenomenon. This means that, although there are some aspects of this language, its formation mechanisms are not yet clear to him because they belong to a more archaic symbolism, which is outside the field of neuroses. Although Miller acknowledged that the phenomenon is not restricted to only one type of personality, he did not get much attention in the theoretical concept, which was developed entirely under the notion of a specific psychic structure that presents difficulties in symbolic processes and had somatization as the consequence.
There was no further information about what can lead to psychosomatic, psychotic, or autistic outputs because for Miller (1987) these structures are very close. Moreover, it is not explicit why a failure in symbolization in any confined area may not have the return in form of delusion or acting outs. What is noticed is that these phenomena have a resemblance to psychoses, both in their mechanisms, as in the family structure. The lack of symbolization, the fact of not having been conceived and significantly represented by their parents, is common to these two structures, resulting in a gap in the answers that might exist on the choice of one way or another.

Joyce McDougall, somehow, overcomes these theoretical elucidations to recognize that there is not a specific subjective structure of psychosomatic phenomena. Moreover, in her book Body Theatres (McDougall, 1996), the author discusses somatization as any kind of acting out, including the use of substances, increased vulnerability to physical accidents, and failures of the immune system.

To name this very common mechanism in psychosomatic subjects in which affection is not thought, McDougall coined the term disaffection. Affection is a limit concept, as well as a drive concept, standing between somatic and psychic. Basically, the state of disaffection consists in an inability to think about intensely experienced emotions. The fact that these people experiences strong emotions is not as impaired, although there is always an attempt to escape from these experiences. However, the ability of naming, differentiating, and reflecting on their most intense emotional states is almost null. In addition to the projection of affection, the disaffection is a mechanism that also projects out the representation. At this point, McDougall defines a new destination for the affections, the repudiation out of ego, to add to the three already existing ones (shift, conversion, and transformation into anxiety). The affection that was ejected in its psychic part, remains only to express itself through its organic dimension, as in early childhood, thus reducing the psychic message to a non-verbal performance. 
At first glance, there are some similarities with operational thinking described by the Psychosomatic Institute of Paris, especially with respect to the break on conscious/unconscious systems, resulting in a pragmatic and concrete psychic functioning. However, in the case of operational thinking, there is also an inability to experience these emotions, which can occur in disaffection, but not necessarily as a rule.

There is some similarity between mechanisms of disaffection, foreclosure, and projection as they have brutal effects and ideational representation removing mechanisms. The differences lie in the fact that on projection the content is deleted and drive is deformed, returning to consciousness as a representation connected to an external object. On disaffection, it is the affection that is rejected to not return to an external or hallucinatory object. Its destiny is to be drained via somatic paths. Therefore, on projection, the representation is not completely thrown out of the psyche, as some representations remain in the external object. On disaffection, perhaps, the whole representative chain is deleted, with no return.

On behalf of the dominant anxieties within the framework of psychosomatic illnesses, these are much closer to psychotic anxieties than to hysterical ones, basically referring to loss of individual and sexual identity, as well as the body limits. These early fears leave psychological traces on any individual, the ones related to fears of every baby and which are mostly solved in the phallic-oedipal phase. However, when they remain unresolved and psychotic anxiety dominates the clinical picture, we are no longer facing a hysterical problem, although psychosomatic patients also are not psychotic. "Perhaps, we are in a position to ask ourselves if many neurotic, hysterical, and obsessive organizations are not, at heart, built from a psychotic core" (McDougall, 1996, p. 21).

A lot is said in the texts reviewed on the etiology of psychosomatic illnesses. Joyce McDougall at this point does not differ much from other authors. An aggressive family organization and consequent mental poverty that leads to a disease are factors cited in almost all works. But little is said about the metapsychological mechanisms that dissipate it. Although the author has created a new concept, the disaffection, little is understood about its specificity. The disaffection, defined as the rejection out of the ego, is a mechanism similar to the psychotic use of foreclosure (a term used by the Lacanian school), or projection (the term used by the English School). The author emphasizes the affective dimension that is divorced - maybe that is the difference to foreclosure - ejecting only the representation, with no emotional charge. Moreover, little is said about the formation of the disease based on this mechanism. Only a short passage appears, which states that when the psychic dimension of affection is divorced, the organic dimension is expressed. Moreover, it states that the disaffection is not a return in the form of delusion, as on foreclosure or projection. If the disaffection, the whole representative chain is destroyed, how can its return to the body in a precarious form of symbolization be explained? It also begs the question of why the return does not come out in a delusional form.

Little has also been said on the elements that could be used in building a symbolical sense. We know that it does not configure symbolization form as in hysteria, being much more archaic, but we do not know what concepts can be called to solve it. On this point, the next author adds very important theoretical contributions, sticking to the importance of not representing aggressive dimensions in somatization, brought by a similar mechanism, which he called unconscious cleavage. Moreover, the author seeks to explain and offer a solution to questions that are not answered by previous authors on the issue of the element that differ between a psychosomatic or psychotic output, based on the observation of differences between psychotic and psychosomatic parents. But before it is necessary to explain some basic concepts of his theory, as its own definition of psychosomatic illnesses, the notion of libidinal subversion and the construction of erogenous body.

Dejours (1991) points out that, in his view, if there is a dualism it is that between erogenous body and physiological body, not from an op- 
posite relation standing point, but in a way that the latter can overcome the former. Nonetheless, the construction of the erogenous body is never completely successful, and there may be gaps in the convening of an organ, or also unlinking the drive from some area, due to a trauma occurred in the life of the subject. This is how the question of the organ of choice is treated: the body areas that have not been sufficiently subverted are easily reached in somatization.

Despite the similarity with the theory of Lacan, with regard to the issue of the organ of choice, there are different opinions regarding the origin of the drive. To Dejours (1991), the drive comes from a biological, innate source, while to Lacan - and post-Lacanian authors - the drive comes from language and specifically from significance that the mother figure introduces to the baby in his first months of life.

After this initial approach to the basic principles that guide his theory, some specific questions about the problem of somatization will be addressed, such as the third topic (cleavage topic), and will not represent aggressive dimension as the central problem of psychosomatic illnesses.

The aggressiveness that could not be represented is due to the unconscious cleavage in primary/secondary unconscious. The author takes up the Freudian hypothesis of the unconscious as being also made up of phylogenetic features, considering the primary unconscious as the host of inherited traits. The secondary unconscious, in turn, is that linked to symbolic representations. The death drive that is prevented from being represented by the pre-conscious operates destructively on the organic body through psychosomatic diseases. Thus, the subject remains unknown of his own violence. Trying to preserve the apparent normality in social bonding, this violence is not acted out, but directed against the subject himself, which strikes a blow against the very unconscious body in the form of somatization. Dejours (1991) suggests that the somatization itself may act as symbolizing some lost aspect of the history of these people. This is another innovation in the field of psychoanalytic psychosomatic because until now, no author had mentioned the possibility of seeing somatization as a facilitator for rolling out the analysis process. The violence of the analyzing patient is not concretely expressed. More subtly, it is perceived in a negative manner: missing words that signify emotional experiences in his speech, as well as more spontaneous and authentic body and facial expressions.

Another defense mechanism is proposed in an attempt to explain the somatization process: the suppression of aggressive affects. This mechanism seeks to eliminate the affects from its source, which, according to the author, is biological. It differs from the regular repression mechanism because it operates only on the representations at the pre-conscious/ unconscious level, preventing the repressed unconscious representations beyond the barrier to the preconscious. In this case, the conscious completely loses touch with the repressed content, while in repression, the representation appears sometimes intact to conscious and may disappear soon after. Unlike repression, suppression operates at the conscious/preconscious level. It more specifically opposes the development of affect and not the ideational representational element. Therefore, we can see that repression operates more on the psychic level of representations, while suppression operates more on the affective and body level.

According to that, the author states that to interpret a psychosomatic symptom is, effectively, to interpret the death drive. This is a process that seeks to link the death drive with the life drive, emptying its traumatic potential. The symbolization somatization should be identified, according to the author, eliminating the essential depression hypothesis. Therefore, he considers all the theoretical propositions of the IPSO, but differentiates between types of somatization: progressive disorganization is different from symbolization somatization. In the first, the violence is partially inhibited, whereas in the second it is massively suppressed. What is observed, then, is that some somatization opens the way to reveal a conflict or a part of the history of 
the subject that remained hidden, which he did not get into contact, due to its traumatic fashion. From this, it was observed that during the analysis, the one which once seemed apparently frozen, it began to unfold and also evoked the notion of "psychosomatic facilitation" (Dejours, 1991, p. 28).

Similarities were also very often found with the mother/baby relationships of psychotics. Dejours (1991) points out that the difference lies in the fact that the psychotic parents seek to divert the thoughts of the children, creating an alienated child with no original thought. Parents of psychosomatics, however, seek to destroy any kind of thought they might have, especially of a sexual nature. But it is not only in this respect that in Dejours theory these psychopathologies become close: he proposes a hypothesis that mental illness, especially psychoses, should be aggregated to psychosomatic illnesses. At this point, the author takes into account the findings of neuroscience, according to which these functions depend on the hereditary assembly of the nervous system. Thus, it is also thought that in the case of psychoses, the unlink with drive, instead of happening in visceral areas - as with psychosomatic illnesses - occurs in the brain, affecting areas related to cognition and language, which are the most compromised functions in psychotics.

Dejours (1991) and McDougall (1996) offer a greater advance in the technique, in the sense that an interpretative work is risky, and therefore more operative, although Dejours (1991) also consider the relevance of the Marty therapy procedure he called stop-excitation. The choice between the two treatment procedures, he said, depends on the willingness of the analyzing subject to face his truth. From a clinical point of view, Dejours (1991) offers an innovative finding that the somatization also occurs in neurotic personality structures. As regards the technique, the author also asserts a new proposition that the somatic subjects must be interpreted through their aggressive and deadly contents. For him, therefore, an underlying meaning to the disease can be unraveled, seeking to link the traumatic dimension of the death drive into libido.

\section{Discussion}

Although there are some theoretical differences, as already noted, the opinions about the psychosomatic phenomena follow a certain pattern, concerning the characteristics of patients who have this type of suffering. There is consensus regarding the failure of symbolization present in these clinical cases, although theories have followed a motion at the beginning, considering the lack of symbolization as structuring these cases, unfolding to the notion that this lack is not structural but limited to some parts of the speech. Also lingers in general, the agreement regarding the lack of affection, references to the lack of dream and fantasy life, and an extreme concreteness of thought, concomitantly with an extremely pragmatic lifestyle. All these factors are listed and called "operational thinking" by members of the IPSO and "alexithymia" by the Psychosomatic School of Chicago. Joyce McDougall uses the defensive mechanism of disaffection to designate the same characteristic elements. Dejours does not go far enough in creating a new concept to denote these personality characteristics, and the emphasis of his theory lies in the unconscious cleavage hypothesis and the size of the disclosed aggression. However, theoretical incursions of post-Lacanian authors, as with Miller, points to the consideration of other defensive mechanisms that can coexist with foreclosure, giving the idea that the foreclosure of the Name of the Father does not establish the general logic of symbolization in psychosomatic cases, as occurs in psychotic, but is a limited mechanism that can coexist with repression, and denial. However, still a psychosomatic patient profile is maintained, and this is very close to the psychotic profile, which seems to remain a contradictory opinion with the rest of the theory, even missing more theoretical elements to analyze the occurrence of somatization within the well mentalized subjectivities. McDougall's ideas move toward the approach of psychosomatic with hysteria, agreeing with the symbolic dimension that the phenomenon offers, but more archaic than the symptom. 
The approach of psychosomatic with psychosis is also performed by Dejours; however, with the difference that, in the present day, there is a proposal to treat diseases known as "mental" as psychosomatic diseases, where there would be an unlinking of the drive and, therefore, a vulnerability to the death drive. This would explain why psychotic and autistic subjects can be damaged in language and cognition functions, while their immune system remains extremely strong. Dejours offers a clue to a better understanding of the differences found in psychotic and psychosomatic outcomes. Despite the similarities between the two, we see that there is a difference with the destinies of the thoughts of patients in early childhood. Moreover, the important role played by parents in body areas' libidinization, which, he said, could be decisive between a psychotic or a psychosomatic outbreak, is also notable.

With regard to discussions on the allocation of a symbolic meaning about the disease and the metapsychological mechanisms involved in it, some progress was achieved in the course of theories, such as making sense of the disease, which also offers a breakthrough in practice clinics and is shown in this way to be a little more operational. Moreover, some important discoveries about the aggressive dimension present in this issue allowed more enlightening attempts to describe the metapsychology involved in cases of somatization, a fact that is verified on the proposition of the third topic by Dejours.

Thus, although at the beginning the relationship between the symbolization of disability and the outbreak of a bodily disease had been addressed more directly; however, the presence of more metapsychological elements involved in somatization has been noted recently. For example, disaffection mechanism and cleavage of the imago, from McDougall, and topical cleavage and suppression of aggression, from Dejours, are concepts which, in a way, problematized an issue that apparently had a somewhat more simplified and straightforward approach.

Regarding the path followed by discussions on the direction of the psychosomatic phenomenon, we see that the classic initial discussions of psychoanalysis, carried out by members of the IPSO, led to the question whether the phe- nomenon would come to embrace the language structure. Despite this seeming to be the opinion given by Lacan, Miller does not conclude the issue, ranging from statement positions as the absence of any symbolic element or admitting the possibility of an insertion in the language structure. This would open the possibility to classify it as a border phenomenon, which is within the limits of the symbolic universe.

Among French authors, it is only with the introduction of Dejours' ideas that injury is proposed, building a sense for the body; however, unlike the hysterical symptom, which is interpreted through the erotic fantasies repressed by the subject, the psychosomatic phenomenon should be interpreted from repressed aggressive drives. However, Dejours is not considered a strictly post-Lacanian author, remaining unknown positions taken by them today. McDougall, instead, carries an approchement with Dejours' ideas, stressing that somatization is a hidden history of the life of a subject, which was unable to be represented for himself and for someone. Hence, there is a need for (re) construction of this lost history, which would give meaning to somatization. Moreover, despite these advances in the theoretical and clinical framework, the symbolization of psychosomatic phenomena is much more archaic than those of a hysterical symptom. It retains a certain difficulty in its unveiling.

On the movement traversed of the theoretical constructs about a sense, Casetto (2006) notes that

. . Putting up these differences in time perspective, it detects what appears to be a certain movement (dialectical): somatization moves from a model more strictly conversive to his own denial, and then to a third state which appears as a horizon of still unfulfilled meanings. (p. 17)

Despite these advances in the trodden path, a theory that explains all metapsychological mechanisms behind somatization has not yet been developed. Perhaps this difficulty arises by the problematic itself, which is revealed in difficult cases by extreme neutralization with these clinical patients. However, this strengthens the finding that a psychosomatic illness is a 
phenomenon that covers both the biological and psychological dimensions and is therefore necessary to revise our conceptions of the nature of the mind and body and the mode of interaction that occurs between these two. This was made very clear in the work by Dejours from his concept of libidinal subversion; however, although psychoanalysis has revolutionized with the limit concept of drive, it has clung more to theories on psychic mechanisms, thereby lacking explanations when faced with biological and psychological phenomenon. This difficulty has been pointed out by Birman (2001), who considers that this fact - much more than being translated by a theoretical failure - was established by an agreement between psychoanalysis and medicine, operating a separation between the psyche of the issues that must be investigated by the first field and body issues, which are restricted only to the second. This split occurred in the emergence of psychoanalysis and its questioning of the positivist science and should be reviewed through a demand of the psychosomatic reality, which has increased in clinics.

Finally, there is also a need to consider other aspects of constituent psychosomatic phenomenon than only genetic, unconscious, and those built from early relationships with parents. This refers to a greater search for answers in the social life of a subject because, if psychosomatic illnesses are increasing today, there would not be elements in our contemporary society, which contribute to a psychic malaise that is expressed through the body increase.

The discussion extends to an observation of the functioning of our society in which labor relationships reflect only one aspect of its operation. The values spread by social media such as individualism, consumerism, and competition would be contributing to the construction of fragmented, depersonalized identities:

The question is: does the contemporary capitalist society, with its supreme link to consumption values, would not be producing a kind of depersonalization that come along with mass culture phenomenon? Do we live in a culture whose imperatives favor the appearance of normosis disease? Here is a broader hypothesis, to be worked at anoth- er time, that the fragmentary lifestyle that gives us the contemporary society, after all, doesn't favor what you might call a good mentalizing. (Ferraz, 1997, p. 172)

This is an interesting and necessary debate for psychoanalysis, which offers the possibility to think about the construction of subjectivity beyond what was established in the family relationships during early childhood. It seeks to integrate present aspects of a subject's life - both relational and psychological distress at work with discussions of the historical and social context in which it is inserted. This is an important factor, which establishes greater relationships with the external and relational environment without leaving aside the intrapsychic dynamics.

\section{Final Considerations}

Discussions in psychosomatics have mostly followed a certain theorizing pattern, particularly with regard to symptoms and psychological functioning. These descriptions were characterized as a concrete work, pragmatic and devoid of symbols and dream life. As we saw in Miller and Pierre Marty's works, the idea of a psychosomatic personality structure is stronger. The first incursions of Lacan do not leave much clear, since he considered that psychosomatic illnesses would be analyzable in the limit to be considered a phenomenon of the real body order. Perhaps, this is why he did not include psychic structures in the psychosomatic ratings. However, it implies the question of a structural mechanism of foreclosure of the Name of the Father who approaches the psychosomatic from the psychotic and autistic structures. However, Miller says the psychosomatic phenomenon is a threshold phenomenon because it adheres in some respects - as yet unknown - to the language structure. Would it be appropriate to consider, as from Lacan's perspective, the possibility of thinking about psychosomatic as a boundary arrangement, as it does not present itself as a neurotic functioning but has exceeded the psychotic organization? It has been observed that the symbolization is not absent, as is the psychotic organization, but it is from a more archaic order than what happens with neurotics. 
Although McDougall and Dejours have recognized the phenomenon beyond this type of psychic functioning, their theorizing is still transiting in this area, with McDougall discoursing on the disaffection and Dejours on the suppression of aggression. Therefore, the mechanisms that were behind the somatization in more neurotic psychic functioning are still lacking in explanations and metapsychological elucidations.

Regarding the difficulties encountered in the research process, these reside in the very difficulty inherent in the subject: that little is explored by psychoanalytic authors, and when they do, they perform a directed theory for the negative and symbolic inability of such subjectivity is cited by all authors reviewed. Moreover, while acknowledging that psychosomatic diseases are not restricted only to the operative mode, there are few elements to think about this problem out of the framework set by Pierre Marty. Moreover, the works related to this subject are often terse and somewhat didactic in his explanation. In this sense, there was much difficulty in the lack of explanation of concepts and even concrete examples for a better understanding. Perhaps, in a broader sense, psychoanalysis is still a little layperson when it comes to the subject of psychosomatic and the works revised go in the same direction of general mechanisms of explanation and description, thereby lacking some new contribution elements to think about this problem.

Our impressions agree with the view that psychosomatic illnesses are much more frequent and much less stringent than suggested by the traditional authors of psychoanalytic psychosomatic. Perhaps, a clue to identify the occurrence of a psychosomatic illness is to stick to the facts triggering injury in the life of the subject, which differ from other diseases whose etiology may be attributed to more organic and less psychological causes. We also believe that discussions about the definition of psychosomatic and not psychosomatic diseases should be reviewed, as it is also known that the occurrence of some trauma (mourning, separation) triggers organic diseases and they should be considered more psychosomatic than those that do not carry a trigger related to an emotional event. Finally, we reiterate the importance of establishing a dialogue with the modes of subjectivity production that are in course in our society because psychoanalysis leads existing discussions between the current capitalist way of production and illness at work.

\section{References}

Birman, J. (2001). Corpos e formas de subjetivação em Psicanálise. Estados Gerais de Psicanálise. Retrieved from http://egp.dreamhosters. com/encontros/mundial_rj/download/3_Birman_38020903_port.pdf

Casetto, S. J. (2006). Sobre a importância de adoecer: Uma visão em perspectiva da psicossomática psicanalítica no século XX. Psychê, 10 (17), 1-22. Retrieved from http://pepsic.bvsalud. org/scielo.php?script=sci_arttext\&pid=S1415$11382006000100008 \& \operatorname{lng}=\mathrm{es} \& \mathrm{nrm}=$ iso

Dejours, C. (1991). Repressão e subversão em psicossomática: Pesquisas psicanaliticas sobre o corpo. Rio de Janeiro, RJ: Jorge Zahar.

Ferraz, F. C. (1997). O mal-estar no trabalho. In R. M. Volich, Psicossoma: Psicossomática Psicanalítica II. São Paulo, SP: Casa do Psicólogo.

Leclaire, S. (1992) O corpo erógeno: Uma introdução à teoria do complexo de Édipo. São Paulo, SP: Escuta. (Original work published 1979)

McDougall, J. (1996). Teatros do corpo: O Psicossoma em psicanálise ( $2^{\text {nd }}$ ed.). São Paulo, SP: Martins Fontes.

Mello, J., Filho, \& Burd, M. (Eds.). (2010). Psicossomática hoje ( $2^{\text {nd }}$ ed.). Porto Alegre, RS: Artmed.

Miller, J.-A. (1987). Algumas reflexões sobre o fenômeno psicossomático. In R. Wartel, Psicossomática e Psicanálise (pp. 87-97). Rio de Janeiro, RJ: Jorge Zahar.

Vieira, W. de C. (1997). A psicossomática de Pierre Marty. In F. C. Ferraz \& M. R. Volich, Psicossoma: Psicossomática Psicanalítica (pp. 15-22). São Paulo, SP: Casa do Psicólogo.

Volich, R. M. (2000). Psicossomática (2 ${ }^{\text {nd }}$ ed.). São Paulo, SP: Casa do Psicólogo.

Recebido: 08/10/2015 Aceite final: 14/01/2016 